\title{
Causes and suggested remedies to taro endangerment in four regions of Ghana
}

\author{
Emmanuel Oduro ${ }^{1 *}$ (D) Esther Fobi Donkor ${ }^{2}$ (D) and Emmanuel Ackah ${ }^{3}$ (B)
}

\begin{abstract}
Background: Many plant species worldwide cultivated for food have been neglected and are being underutilized despite their crucial contributions to food security, nutrition and income generation to rural citizens, leading to a nearly permanent diet deficiency. Taro (Colocasia esculenta (L.) Schott), an important food crop in the family Araceae, is one of the neglected species. This study therefore focused on identifying potential challenges mitigating taro production and utilization in taro-producing areas of Ghana and to formulate recommendations for overall increased production and utilization of the crop. The study was conducted in Ahanta West Municipal, Dormaa Municipal, Kumasi Metropolitan and East Akim Municipal in the Western, Bono, Ashanti and Eastern Regions of Ghana, respectively. These districts were ever known for taro production in Ghana. Well-structured questionnaires were used to collect information on ethnobotany of taro, possible causes of taro endangerment and remedies to combat them from farmers, traders and consumers.

Results: The survey revealed different vernacular names for taro, and the corm was the main part used as food. The corms were usually boiled before eaten. Major recipes of taro identified were "Puree and Ampesi."The study revealed that taro was mainly cultivated on marginal soils as well as near water bodies. Taro was largely cultivated on subsistence scale. The study also revealed that utilization as food and tool of trade has reduced drastically. Major causes of taro extinction reported included: lack of healthy planting materials, unavailability of consumable corms and disease [Taro leaf blight disease(TLBD)] of the crop.
\end{abstract}

Conclusion: It was suggested that the release of cultivars which are resistant to the TLBD and publication of the nutritional benefits of the crop could revive the cultivation and utilization of the crop.

Keywords: Ashanti, Bono, Causes, Eastern, Remedies, Taro, Western

\section{Background}

Many plant species worldwide cultivated for food have been neglected and underutilized despite their crucial contributions to food security, nutrition and income generation to rural citizens (Akpavi et al. 2012; Barbieri et al. 2014). This has led to a nearly permanent diet deficiency. Unsustainable crop, livestock, forestry, fisheries and aquaculture practices, including other unsustainable productive systems such as industries and mining and

\footnotetext{
*Correspondence: nanaoduro865@gmail.com

1 Plantation Department, Norpalm Ghana Limited, Takoradi, Western

Region, Ghana

Full list of author information is available at the end of the article
}

urbanization processes, are increasingly degrading the wealth of our biodiversity and the health of our ecosystems. Modern food systems are seriously affecting both food production and consumption patterns, with just five crops, namely rice, wheat, maize, millet and sorghum providing about half of human food energy needs. The use of such a small number of species, often with a narrow genetic base, increases the vulnerability of production systems and puts food security and nutrition at risk (Subedi et al. 2020).

Taro (Colocasia esculenta (L.) Schott), an important food crop in the family Araceae, is one of the neglected species (Onwueme 1999; Quero-Garcia et al. 2010). Taro ranks fourteenth among the world's staple 
vegetable crops with a global harvest of about 9.2 million tonnes from 1.8 million hectares of the world agricultural land and an average yield of $5.1 \mathrm{t} \mathrm{ha}^{-1}$ (Taylor et al. 2010). Taro is cultivated mainly for home consumption in most continents including Asia, Africa, Papua New Guinea and PI (Ecoport 2010; Safo-Kantaka 2004). It has greatest significance in the Pacific, where it has special cultural, dietary and economic importance. In many PI countries, it is considered an important component of every meal. The highest areas of production, however, are in West Africa (Ofori 2004). It also serves as an essential export commodity in several countries, including Fiji and Cook Islands, and it was in Samoa before 1993 (Taylor et al. 2010). The crop also contributes to food security and has rich economic and sociocultural connotations in Africa (Darkwa and Darkwa 2013; Mwenye 2009; Onyeka 2014).

Currently, taro is among the crops that produce the lowest average yields (5.4 tonnes/ha for the world) of all reported root crops (FAOSTAT 2015). In the past, major producers of taro globally were largely dominated by West African countries (McGregor et al. 2011). Africa produced 9.5 million tonnes of the estimated 12 million tonnes of taro produced in the world in 2007, while 2 million were produced in Asia. In Ghana, the yield of taro decreased from 7.1 tonnes/ha in 2015 to 6.2 tonnes/ha in 2017 (FAOSTAT 2017). According to WAAPP-Ghana, the mean annual production growth rate of taro has declined by $3.4 \%$ since 2005 . Decline in productivity could be attributed to lack of improved varieties in the farming system (website: https://waapp. org.gh).

In Africa, Nigeria is the leading producer of taro, followed by Ghana with a production capacity of $5,387,000$ and $1,688,330$ tonnes, respectively, compared to Papua New Guinea and Guinea with 285,000 and 31,200 tonnes (FAO 2008).

A study by Antwi et al. (2017) indicated that TLB and lack of planting materials are the main constraints to large-scale production. More information is required on on-farm production practices, harvesting, handling, storage, utilization as well as germination protocols. Awareness of the benefits and value of maintaining taro landraces also needs to be increased among farmers (Taylor et al. 2010). Regrettably, research in taro production, processing, marketing and consumption appears to be neglected probably because of the apparent lack of interest in the crop.

This study, therefore, sought to identify possible setbacks while formulating appropriate recommendations for increasing productivity and utilization of Colocassia esculentus in the major taro-producing regions in Ghana.

\section{Methods}

\section{The study areas}

The study was a cross-regional study that covered four taro-producing regions in Ghana including the Western, Bono, Ashanti and Eastern Regions. One district each, ever known for taro production within the regions, was the main focus of this study (using field survey), i.e., Ahanta West Municipal in the Western Region, Kumasi Metropolitan in the Ashanti Region, Dormaa Municipal District in the Bono Region and East Akim Municipal in the Eastern Region.

\section{Ahanta West Municipal}

Ahanta West Municipal District is located within longitude $1^{\circ} 50^{\prime} 907^{\prime \prime} \mathrm{W}$ and latitude $4^{\circ} 53^{\prime} 056^{\prime \prime} \mathrm{N}$, at the southernmost point of the country. The entire West African Sub-Region with its capital at Agona Nkwanta is bounded to the East by the Sekondi-Takoradi Metropolitan Assembly (STMA), the West by the Nzema East Municipal, and to the North by Mpohor Wassa East District and Tarkwa-Nsuaem Municipal and the Gulf of Guinea to the South. The district falls within the southwestern equatorial climatic zone of Ghana. The highest mean temperature is $34{ }^{\circ} \mathrm{C}$ which is recorded between March and April, while the lowest mean temperature of $20{ }^{\circ} \mathrm{C}$ is experienced in August. Relative humidity is very high averaging between 75 and 85 percent in the rainy season and 70 percent to 80 percent in the dry season. The district is located in the wettest region of Ghana. It experiences a double maxima rainfall of over $1,700 \mathrm{~mm}$. The rainy season is between the months of April and September, with the greatest volume recorded between April and July (GSS 2014).

\section{Kumasi Metropolitan}

The Kumasi Metropolis is located between latitude $6.35^{\circ} \mathrm{N}$ and $6.40^{\circ} \mathrm{S}$ and longitude $1.30^{\circ} \mathrm{W}$ and $1.35^{\circ} \mathrm{E}$ and elevated 250 to $300 \mathrm{~m}$ above sea level. The Metropolis shares boundaries with Kwabre East and Afigya Kwabre Districts to the north, Atwima Kwanwoma and Atwima Nwabiagya Districts to the west, Asokore Mampong and Ejisu-Juaben Municipality to the east and Bosomtwe District to the south. The Metropolis falls within the wet sub-equatorial type. The average minimum temperature is about $21.5^{\circ} \mathrm{C}$, and the maximum average temperature is about $30.7^{\circ} \mathrm{C}$. The average humidity is around 84.16 per cent at sunrise and 60 per cent at sunset. It has a double maxima rainfall regime (214.3 $\mathrm{mm}$ in June and $165.2 \mathrm{~mm}$ in September). The Metropolis lies within the transitional forest zone but 
specifically within the moist semi-deciduous SouthEast Ecological Zone (Ghana Statistical Service 2010).

\section{Dormaa Municipal}

The Dormaa municipality is situated at the western part of the Brong Ahafo Region. It lies within longitudes $2^{\circ} 50^{\prime} 533^{\prime \prime} \mathrm{W}$ and $3.30^{\circ} \mathrm{W}$ and latitudes $7^{\circ} 16^{\prime} 261^{\prime \prime} \mathrm{N}$. It is bound in the north by the Jaman South district and in the east by the Dormaa East district, in the south and southeast by Asunafo and Asutifi districts, respectively, in the west and southwest by Dormaa West and in the west and northwest by La Cote d'Ivoire. The municipal capital is Dormaa Ahenkro, located about $80 \mathrm{kms}$ west of the regional capital, Sunyani. The highest point of the district is a little over $375 \mathrm{~m}$ above sea level. The municipality is located within the wet semi-equatorial climate region with a double maxima rainfall regime. The mean annual rainfall is between 125 and $175 \mathrm{~mm}$. The first rainy season starts from May to June, with the heaviest rainfall occurring in June, while the second rainy season is from September to October. The dry seasons are quite pronounced with the main season beginning around the latter part of November and ending in February. It is often accompanied by relative humidity of $75-80$ percent during the two rainy seasons and 70-72 percent during the rest of the year. The highest mean temperature is about $30{ }^{\circ} \mathrm{C}$ and occurs between March and April and the lowest about $26.1{ }^{\circ} \mathrm{C}$ in August. The major vegetation types are the semi-equatorial forest, semi-deciduous forest and high grassland (Nyarko 2010).

\section{East Akim Municipal}

The municipality is bounded by six districts, namely Atiwa District to the north, West Akim District to north west, Fanteakwa District to the East, New Juaben to the south, Yilo Krobo District to the south east and Suhum/ Kraboa/Coaltar District to the west. The municipality lies in the west semi-equatorial zone which is characterized by two main rainfall seasons occurring in June and October; the first rainy season starts from May to June and the second from September to October. The mean annual rainfall is between 125 and $175 \mathrm{~mm}$. The dry seasons are distinct starting between November and late February. Temperatures are found to be fairly uniform ranging between $26{ }^{\circ} \mathrm{C}$ in August and $30{ }^{\circ} \mathrm{C}$ in March. Relative humidity is generally high throughout the year, ranging between 70 and $80 \%$ in the dry season and 75 and $80 \%$ in the wet season. The municipality lies within the moist semi-deciduous forest (MoFA 2010).

\section{Field survey and data collection}

Well-structured questionnaires, on ethnobotany, causative factors and remedies of taro endangerment were administered to 50 respondents each from the selected regions, resulting in 200 respondents. The respondents came from three towns/villages randomly selected from each district and were comprised of comprised of 20 farmers, 20 traders and 10 consumers of taro who were subjected to the same questions. In relation to ethnobotany, respondents were interviewed on local vernacular name of accession, cooking methods and time used, available recipes, parts of plant used, palatability, uses, growing conditions, cultivars grown and importance of taro, while questions on the causes of taro endangerment and possible remedies revealed the various causes of endangerment (socioeconomic, cultural or agriculture related) as well as possible solutions for general recommendations. Open-ended discussion was used in the interviews. A response corresponding to each answer provided to the questions in the surveys was scored one point as well as other answers provided by respondents. The surveys were conducted during the rainy season (May to September 2020), to help gather further information through farm visits.

\section{Statistical analysis}

The data collected from the field survey were coded and were statistically analyzed using Statistical Package for the Social Scientist (SPSS), version 25 software. Descriptive statistics including frequencies and percentages were used to describe the various parameters obtained from the field survey.

\section{Results}

\section{Characteristics of respondents}

Analyses of responses collated from respondents from the three regions with respect to their age, gender, educational status and occupation are presented in Table 1. Of the 200 interviewed, 151 (75.5\%) were men, whereas the rest $49(24.5 \%)$ were women. The regional divisions included 33, 35, 43 and 40 males as well as 17, 15, 7 and 10 females in the Ashanti, Bono, Western and Eastern regions, respectively. For the age of respondents, 61-70 years (16/ 8.0\%) represented the lowest number of respondents, while $41-50$ years $(73 / 36.5 \%)$ represented the highest number of responses in all regions which included 16, 18, 19 and 20 in the Ashanti, Bono, Western and Eastern regions, respectively. Of the 200 respondents, 114 (57.0\%) were JHS leavers, followed by 39 (19.5\%) illiterates and 34 (17.0\%) primary school leavers. Thirteen (6.5\%) were SHS leavers, and none of the respondents (0) had attended the tertiary level. The highest number of respondents in the regions was 29 each with JHS status from the Ashanti, Bono and Eastern regions and 27 from the Western region, whereas the lowest which were of the SHS status was 1 from the Ashanti and Bono regions, 6 
Table 1 Demographic characteristics of respondents (cross-tabulation)

\begin{tabular}{|c|c|c|c|c|c|c|}
\hline \multirow[t]{2}{*}{ Item } & \multirow[t]{2}{*}{ Responses } & \multicolumn{4}{|c|}{ Respondent's region of residence } & \multirow[t]{2}{*}{ Total } \\
\hline & & Ashanti & Bono & Western & Eastern & \\
\hline \multirow[t]{6}{*}{ Respondent's age group } & 20-30 years & 12 & 12 & 9 & 9 & 42 \\
\hline & $31-40$ years & 11 & 11 & 10 & 11 & 43 \\
\hline & $41-50$ years & 16 & 18 & 19 & 20 & 73 \\
\hline & $51-60$ years & 7 & 5 & 7 & 7 & 26 \\
\hline & $61-70$ years & 4 & 4 & 5 & 3 & 16 \\
\hline & Total & 50 & 50 & 50 & 50 & 200 \\
\hline \multirow[t]{3}{*}{ Gender } & Male & 33 & 35 & 43 & 40 & 151 \\
\hline & Female & 17 & 15 & 7 & 10 & 49 \\
\hline & Total & 50 & 50 & 50 & 50 & 200 \\
\hline \multirow[t]{6}{*}{ Level of education } & Primary & 8 & 10 & 8 & 8 & 34 \\
\hline & Junior high & 29 & 29 & 27 & 29 & 114 \\
\hline & Senior high & 1 & 1 & 6 & 5 & 13 \\
\hline & Tertiary & 0 & 0 & 0 & 0 & 0 \\
\hline & Illiterate & 12 & 10 & 9 & 8 & 39 \\
\hline & Total & 50 & 50 & 50 & 50 & 200 \\
\hline \multirow[t]{4}{*}{ Occupation } & Farmer & 42 & 41 & 40 & 41 & 164 \\
\hline & Farmer and trader & 8 & 5 & 10 & 9 & 32 \\
\hline & Trader & 0 & 4 & 0 & 0 & 4 \\
\hline & Total & 50 & 50 & 50 & 50 & 200 \\
\hline
\end{tabular}

from the Western and 5 from the Eastern region. Two occupations including farming and trading which are related to taro production were considered in the study. Of the total respondents, $164(82.0 \%)$ were farmers and $32(16.0 \%)$ were farmers as well as traders, while only 4 (2.0\%) were traders.

\section{Ethnobotany of taro}

Information on the ethnobotany of taro included local name, uses, parts of the crop used, period of usage, cooking methods and recipes of taro in the study areas (Table 2). Five local names including 5 munits (3), Asu kooko (49), Brobe (58), Antwebo (46) and Kooko (44) were given by the respondents. Two of the local names, that is, Brobe and Kooko, were given by respondents interviewed in the Ashanti and Eastern regions. Asu Kooko and Kooko were given by respondents in the Bono region, whereas $5 \mathrm{~min}$, Antwebo and Kooko were given by respondents in the Western region. All respondents $(100 \%)$ indicated that taro is used as food.

In terms of parts used as food, 161 (80.5\%) respondents use the corm only, whereas the rest (39) representing 19.5\% feed on both the corm and leaves as food. Forty respondents each from Ashanti, Bono and Eastern regions as well as 41 from the Western region use the corm only as food, whereas 10 from the Ashanti, Bono and Eastern regions as well as 9 from the Western region use both the corm and leaves as food.

For the period of usage, 175 (87.5\%) respondents, that is, 42, 40, 48 and 45 from the Ashanti, Bono, Western and Eastern regions, respectively, use taro whenever available regardless of the season, while the remaining (25/12.5\%), that is, 8, 10, 2 and 5 from the Ashanti, Bono, Western and Easter regions, respectively, use taro in the dry season only.

Two major cooking methods were identified. 162 $(81.0 \%)$, that is, $45,50,30$ and 37 from the Ashanti, Bono, Western and Eastern regions, respectively, boil taro before consuming, while 5 (2.5\%) including 1 from Ashanti, 2 from Western and 2 from Eastern regions fry taro before consuming. Conversely, 33 (16.5\%) respondents, that is, 4, 18 and 11 from the Ashanti, Western and Eastern regions, respectively, either boil or fry taro before consuming.

The survey also revealed Ampesi, taro chips and Puree as the recipes of taro. 64 respondents including 17, 20, 12 and 15 from the Ashanti, Bono, Western and Eastern regions, respectively, prepare Ampesi from taro, 9, that is, 2, 4 and 3 from the Ashanti Western and Eastern regions preferred Puree from taro, while 5, that is, 1, 2 and 2 from the Ashanti, Western and Eastern regions, prepare chips from taro. 26 respondents, that is, 4, 13 and 9 from the Ashanti, Western and Eastern regions, respectively, 
Table 2 Ethnobotany of taro in the study areas

\begin{tabular}{|c|c|c|c|c|c|c|}
\hline \multirow[t]{2}{*}{ Item } & \multirow[t]{2}{*}{ Responses } & \multicolumn{4}{|c|}{ Respondent's region of residence } & \multirow[t]{2}{*}{ Total } \\
\hline & & Ashanti & Bono & Western & Eastern & \\
\hline \multirow[t]{6}{*}{ Local name } & $5 \mathrm{~min}$ & 0 & 0 & 3 & 0 & 3 \\
\hline & Asu kooko & 0 & 49 & 0 & 0 & 49 \\
\hline & Brobe & 12 & 0 & 0 & 46 & 58 \\
\hline & Antwebo & 0 & 0 & 46 & 0 & 46 \\
\hline & Kooko & 38 & 1 & 1 & 4 & 44 \\
\hline & Total & 50 & 50 & 50 & 50 & 200 \\
\hline \multirow[t]{3}{*}{ Uses } & Food & 50 & 50 & 50 & 50 & 200 \\
\hline & Medicine & 0 & 0 & 0 & 0 & 0 \\
\hline & Total & 50 & 50 & 50 & 50 & 200 \\
\hline \multirow[t]{4}{*}{ Parts used } & Corm & 40 & 40 & 41 & 40 & 161 \\
\hline & Leaves & 0 & 0 & 0 & 0 & 0 \\
\hline & Corm and leaves & 10 & 10 & 9 & 10 & 39 \\
\hline & Total & 50 & 50 & 50 & 50 & 200 \\
\hline \multirow[t]{4}{*}{ Period of usage } & Rainy season & 0 & 0 & 0 & 0 & 0 \\
\hline & Whenever available & 42 & 40 & 48 & 45 & 175 \\
\hline & Dry season & 8 & 10 & 2 & 5 & 25 \\
\hline & Total & 50 & 50 & 50 & 50 & 200 \\
\hline \multirow[t]{4}{*}{ Cooking methods } & Boiling & 45 & 50 & 30 & 37 & 162 \\
\hline & Frying & 1 & 0 & 2 & 2 & 5 \\
\hline & Boiling and frying & 4 & 0 & 18 & 11 & 33 \\
\hline & Total & 50 & 50 & 50 & 50 & 200 \\
\hline \multirow[t]{7}{*}{ Recipes of taro } & Ampesi & 17 & 20 & 12 & 15 & 64 \\
\hline & Ampesi and taro chips & 4 & 0 & 13 & 9 & 26 \\
\hline & Puree & 2 & 0 & 4 & 3 & 9 \\
\hline & Puree and Ampesi & 26 & 30 & 14 & 19 & 89 \\
\hline & Puree, Ampesi and taro chips & 0 & 0 & 5 & 2 & 7 \\
\hline & Taro chips & 1 & 0 & 2 & 2 & 5 \\
\hline & Total & 50 & 50 & 50 & 50 & 200 \\
\hline
\end{tabular}

prepare Ampesi or Chips from taro, and 89 respondents, that is, 26, 30, 14 and 19 from the Ashanti, Bono, Western and Eastern regions, respectively, also prepare both Puree and Ampesi from taro, while 7, that is, 5 from the Western and 2 from the Eastern regions, prepare either of the three recipes (Puree, Ampesi and Chips) from taro.

\section{Previous information on the availability, cultivation and utilization of taro}

Previous information confirming the availability, cultivation and utilization of taro in the study areas is presented in Table 3. Information on availability included evidence of previous cultivation as well as availability in natural areas if not cultivated. Of the 200 respondents, 172 comprising of 41, 40, 44 and 47 from the Ashanti, Bono, Western and Eastern regions, respectively, responded Yes to previous cultivation of taro, while 28 comprising of 9 , 10, 6 and 3 from the Ashanti, Bono, Western and Eastern regions, respectively, responded No to previous cultivation. These 28 respondents, however, confirmed that taro was previously available naturally in Marshy areas.

Information on previous cultivation included cultivars grown, growth conditions and season of cultivation. Of the 200 respondents, 21 from the Ashanti region only were able to identify the name of the cultivar grown by farmers as Kooko broni, whereas the remaining 179 were unable to identify the name of cultivars grown by farmers. In the Bono, Western and Eastern regions, names of cultivars grown were unknown. Identifiable growth conditions for taro cultivation included well-drained soil, water logged and around water bodies and even soils with marginal fertility. In the Ashanti, Western and Eastern regions, all conditions were confirmed as being suitable for cultivation of taro, whereas in the Bono region, water logged and around water bodies were the confirmed growth conditions. Water logged and around 
Table 3 Previous information on the availability, cultivation and utilization of taro in the study areas

\begin{tabular}{|c|c|c|c|c|c|c|}
\hline \multirow[t]{2}{*}{ Item } & \multirow[t]{2}{*}{ Responses } & \multicolumn{4}{|c|}{ Respondent's region of residence } & \multirow[t]{2}{*}{ Total } \\
\hline & & Ashanti & Bono & Western & Eastern & \\
\hline \multirow[t]{3}{*}{ Evidence of cultivation } & Yes & 41 & 40 & 44 & 47 & 172 \\
\hline & No & 9 & 10 & 6 & 3 & 28 \\
\hline & Total & 50 & 50 & 50 & 50 & 200 \\
\hline \multirow[t]{3}{*}{ Areas of natural availability if not cultivated } & Forest & 0 & 0 & 0 & 0 & 0 \\
\hline & Marshy areas & 9 & 10 & 6 & 3 & 28 \\
\hline & Total & 9 & 10 & 6 & 3 & 28 \\
\hline \multirow[t]{3}{*}{ Cultivars grown } & Kooko broni & 21 & 0 & 0 & 0 & 21 \\
\hline & Unknown & 29 & 50 & 50 & 50 & 179 \\
\hline & Total & 50 & 50 & 50 & 50 & 200 \\
\hline \multirow[t]{6}{*}{ Growth conditions } & $\begin{array}{l}\text { Well-drained soil, water logged, } \\
\text { high rainfall }\end{array}$ & 1 & 0 & 1 & 1 & 3 \\
\hline & Well-drained soil, high rainfall & 1 & 0 & 2 & 2 & 5 \\
\hline & High rainfall & 20 & 15 & 24 & 22 & 81 \\
\hline & Water logged soil, high rainfall & 22 & 22 & 16 & 16 & 76 \\
\hline & Soils with marginal fertility & 6 & 13 & 7 & 9 & 35 \\
\hline & Total & 50 & 50 & 50 & 50 & 200 \\
\hline \multirow[t]{4}{*}{ Season of cultivation } & Rainy season & 46 & 50 & 47 & 1 & 144 \\
\hline & Dry season & 1 & 0 & 1 & 2 & 4 \\
\hline & Both & 3 & 0 & 2 & 47 & 52 \\
\hline & Total & 50 & 50 & 50 & 50 & 200 \\
\hline \multirow[t]{3}{*}{ Respondent ever trading in taro } & Yes & 1 & 0 & 5 & 4 & 10 \\
\hline & No & 49 & 50 & 45 & 46 & 190 \\
\hline & Total & 50 & 50 & 50 & 50 & 200 \\
\hline
\end{tabular}

water bodies and high rainfall were, however, mentioned by most respondents indicating high water requirement of the crop. Most of the respondents (144) comprising of 46, 50, 47 and 1 from the Ashanti, Bono, Western and Eastern regions, respectively, indicated that taro was cultivated during the rainy season, and 4 comprising of 1 each from the Ashanti and Western and 2 from the Eastern regions indicated that taro was cultivated in the Dry season, whereas 51 comprising of 3, 2 and 47 from the Ashanti, Western and Eastern regions indicated cultivation of taro in both seasons.

With the trading in taro, out of the 200 responses obtained, 10 comprising 1, 5 and 4 from the Ashanti, Western and Eastern regions, indicated that they use to trade in taro, while 190 comprising 49, 50, 45 and 46 from the Ashanti, Bono, Western and Eastern regions, respectively, were not taro traders.

\section{Current information on cultivation and utilization of taro}

Information on the current cultivation and utilization of taro is presented in Table 4. For the current cultivation status of taro, 121 respondents which were made up of 26, 30, 34 and 31 from the Ashanti, Bono, Western and
Eastern regions, respectively, indicated that taro is still being cultivated, and 76 comprising 23, 20, 15 and 18 from the Ashanti, Bono, Western and Eastern regions, respectively, did not cultivate taro, while 3 respondents comprising of 1 each from the Ashanti, Western and Eastern regions were not sure, whether taro is still being cultivated. For consumption, 100 comprising of 23, 30, 24 and 23 from the Ashanti, Bono, Western and Eastern regions, respectively, indicated that they still consume taro, while the remaining 100 comprising 27, 20, 26 and 27 from the Ashanti, Bono and Western regions, respectively, do not consume taro anymore. Out of the 10 respondents who previously traded in taro, 4 comprising 2 each from the Western and Eastern regions still trade in taro, while the remaining 6 comprising 1,3 and 2 from the Ashanti, Western and Eastern regions are no more trading in taro.

\section{Possible causes of taro extinction}

Respondents who responded No to current cultivation and utilization of the crop were further interviewed on possible reasons for not cultivating or utilizing the crop presently. Their reasons could, however, be possible 
Table 4 Current information on cultivation and utilization of taro in the study areas

\begin{tabular}{|c|c|c|c|c|c|c|}
\hline \multirow[t]{2}{*}{ Item } & \multirow[t]{2}{*}{ Responses } & \multicolumn{4}{|c|}{ Respondent's region of residence } & \multirow[t]{2}{*}{ Tota } \\
\hline & & Ashanti & Bono & Western & Eastern & \\
\hline \multirow[t]{4}{*}{ Taro is still being cultivated } & Yes & 26 & 30 & 34 & 31 & 121 \\
\hline & No & 23 & 20 & 15 & 18 & 76 \\
\hline & Not really & 1 & 0 & 1 & 1 & 3 \\
\hline & Total & 50 & 50 & 50 & 50 & 200 \\
\hline \multirow[t]{3}{*}{ Taro is still being consumed } & Yes & 23 & 30 & 24 & 23 & 100 \\
\hline & No & 27 & 20 & 26 & 27 & 100 \\
\hline & Total & 50 & 50 & 50 & 50 & 200 \\
\hline \multirow[t]{3}{*}{ Respondent still trading in taro } & Yes & 0 & 0 & 2 & 2 & 4 \\
\hline & No & 1 & 0 & 3 & 2 & 6 \\
\hline & Total & 1 & 0 & 5 & 4 & 10 \\
\hline
\end{tabular}

Table 5 Possible causes of taro endangerment

\begin{tabular}{|c|c|c|c|c|c|c|}
\hline \multirow[t]{2}{*}{ Item } & \multirow[t]{2}{*}{ Responses } & \multicolumn{4}{|c|}{ Respondent's region of residence } & \multirow[t]{2}{*}{ Total } \\
\hline & & Ashanti & Bono & Western & Eastern & \\
\hline \multirow[t]{3}{*}{ Reasons taro is no more cultivated } & Lack of planting materials & 22 & 20 & 11 & 14 & 67 \\
\hline & Declined yield & 1 & 0 & 4 & 4 & 9 \\
\hline & Total & 23 & 20 & 15 & 18 & 76 \\
\hline \multirow[t]{3}{*}{ Reasons taro is no more consumed } & Unavailability & 24 & 20 & 15 & 19 & 78 \\
\hline & Associated ill-health & 3 & 0 & 11 & 8 & 22 \\
\hline & Total & 27 & 20 & 26 & 27 & 100 \\
\hline \multirow[t]{3}{*}{ Type of ailment associated with taro consumption } & Piles & 1 & 0 & 2 & 2 & 5 \\
\hline & Reduced sexual function & 2 & 0 & 9 & 6 & 17 \\
\hline & Total & 3 & 0 & 11 & 8 & 22 \\
\hline \multirow[t]{2}{*}{ Reasons for not trading taro anymore } & Unavailability & 1 & 0 & 3 & 2 & 6 \\
\hline & Total & 1 & 0 & 3 & 2 & 6 \\
\hline
\end{tabular}

causes of taro endangerment which are presented in Table 5.

Out of the 76 respondents who responded No to current cultivation, 67 comprising 22, 20, 11 and 14 from the Ashanti, Bono, Western and Eastern regions, respectively, indicated lack of planting materials and 9 comprising of 1 from the Ashanti and 4 each from the Western and Eastern regions indicated declined yield as the reason for not cultivating taro anymore.

Out of the 100 respondents who responded NO to the consumption of taro, 78 comprising of 24, 20, 15 and 19 from the Ashanti, Bono, Western and Eastern regions, respectively, indicated unavailability of the crop, while 22 which is made up of 3,11 and 8 from the Ashanti, Western and Eastern regions indicated the association of ill-health to the consumption of the crop. Out of the 22 respondents that indicated ill-health in association with the consumption of the crop, 5 comprising of 1 from the Ashanti and 2 each from the Western and Eastern regions indicate piles, while 17 comprising of 2, 9 and 6 from the Ashanti, Western and Eastern regions gave reduced sexual function as some of the sickness associated with the consumption of taro. For trading of taro, the 6 respondents who have stopped trading in taro indicated unavailability of the crop as the main reason for the stoppage taro trading.

\section{Possible remedies of taro endangerment}

Respondents' views on remedial solutions to taro endangerment are presented in Table 6. Farming practices that could help sustain taro production included fertilizer application, irrigation, use of disease-resistant varieties and pesticide usage. Majority of the respondents (190) comprising of 48 from the Ashanti, 50 from the Bono and 46 each from the Western and Eastern regions, respectively, indicated the use of disease-resistant varieties, 
Table 6 Possible remedies to taro extinction

\begin{tabular}{|c|c|c|c|c|c|c|}
\hline \multirow[t]{2}{*}{ Item } & \multirow[t]{2}{*}{ Responses } & \multicolumn{4}{|c|}{ Respondent's region of residence } & \multirow[t]{2}{*}{ Total } \\
\hline & & Ashanti & Bono & Western & Eastern & \\
\hline \multirow[t]{5}{*}{ Farming practices that can sustain taro production } & Fertilizer application & 0 & 0 & 2 & 2 & 4 \\
\hline & $\begin{array}{l}\text { Irrigation, fertilizer application, use of disease- } \\
\text { resistant varieties }\end{array}$ & 1 & 0 & 1 & 1 & 3 \\
\hline & use of disease-resistant varieties & 48 & 50 & 46 & 46 & 190 \\
\hline & Use of pesticides & 1 & 0 & 1 & 1 & 3 \\
\hline & Total & 50 & 50 & 50 & 50 & 200 \\
\hline \multirow{3}{*}{$\begin{array}{l}\text { Encouraging utilization can help sustain taro } \\
\text { production }\end{array}$} & Yes & 50 & 50 & 50 & 50 & 200 \\
\hline & No & 0 & 0 & 0 & 0 & 0 \\
\hline & Total & 50 & 50 & 50 & 50 & 200 \\
\hline \multirow[t]{4}{*}{ Ways to encourage the use of taro } & By exploring and publicizing its nutritional benefits & 42 & 46 & 39 & 39 & 166 \\
\hline & By exploring and publicizing its medicinal benefits & 2 & 0 & 6 & 6 & 14 \\
\hline & $\begin{array}{l}\text { By publicizing the fact that it grows and matures } \\
\text { earlier than most other tuber crops }\end{array}$ & 6 & 4 & 5 & 5 & 20 \\
\hline & Total & 50 & 50 & 50 & 50 & 200 \\
\hline
\end{tabular}

4 comprising of 2 each from the Western and Eastern regions indicated fertilizer application, and 3 comprising of 1 each from the Ashanti, Western and Eastern regions also indicated the use of pesticides, whereas 3 comprising of 1 each from the Ashanti, Western and Eastern regions indicated irrigation, fertilizer application and use of disease-resistant varieties as solutions to sustain taro production.

All the respondents agreed to sustained utilization and production of taro in Ghana. Most of the respondents (166 comprising 42 from the Ashanti, 46 from the Bono and 39 each from the Western and Eastern regions) suggested the exploitation and publication of the nutritional benefits of taro for sustained production. Twenty respondents comprising of 6 from the Ashanti, 4 from the Bono and 5 each from the Western and Eastern regions suggested more education of farmers on the cultivation of taro and information on the available cultivars as a way of sustaining the cultivation of taro. Fourteen respondents, that is, 2 from the Ashanti and 6 each from the Western and Eastern regions, suggested the publication of the medicinal benefits of taro as a way of sustaining its production.

\section{Discussion}

\section{Characteristics of respondents}

In the present study, males were many than females in total sampled population as well as in regional population because most females were probably not interested in the cultivation of taro. Majority of the participants were aged between 20 and 50 years, were of the junior high status in education and were also farmers. Quite a higher number of respondents were aged above 50 years and were illiterate due to the fact that the youth are not engaged in taro production in these agroecological zones. These responses were generally considered as important information of traditional knowledge of cultivating and managing taro tuber crop in the various agroecological zones.

\section{Ethnobotany of taro in the study areas}

Local or vernacular names of cultivated forms of taro identified with this study in the Ashanti and Eastern regions were Brobe and Kooko. Local names of taro identified in the Bono region were Asu Kooko and Kooko and in the Western region were Antwebo, 5 min and Kooko. The only use of taro tubers identified in the three regions is as food. This could be due to lack of adequate knowledge on other benefits of taro including medicinal and as feed for several farm animals. Most of the respondents in the three regions use taro whenever available. Also, most respondents use the corm only, while a few use both the corm and leaves. The leaves are used for the preparation of stew and soup. The main cooking method for taro identified in the survey is boiling and frying method. Boiled corm was perceived as aromatic. Major recipes of taro identified are Puree, Ampesi and taro chips. Peeled corms are either boiled in salted water (Ampesi) or fried and eaten with stew, sauce or soup. The corms are also boiled and smashed into smooth cream called Puree, locally known as "Nnuhuu" in the Twi dialect. The Puree may be eaten raw or with Palm oil.

A similar study by Antwi et al. (2017) revealed local vernacular name for taro as "brobe" and or "kooko" in the Twi dialect in the Ashanti and Eastern regions of Ghana. In their study, 12 respondents knew the local name "brobe" only, 13 used "kooko" only and 19 used both 
"brobe" and kooko" interchangeably. The people of Sefwi of the then Western but now Western-North Region of Ghana were called taro "kuffour" in the Sefwi dialect. Their study also identified that taro was locally called "Antwebo" in Worakese located in the Western region. Antwi et al. reported similarly that taro is being used for food in their survey. Similarly, Antwi et al. reported that most consumers use taro during the harvesting (dry) season when the corms are in abundance. Antwi et al., however, emphasized that only new and younger leaves of taro were edible. Older leaves were reported to cause irritation and mouth sores irrespective of cooking. Acridity is the main anti-nutritive factor of taro due to the presence of needle-like calcium oxalate raphides in the plant (Bradbury and Nixon 1998). Antwi et al. (2017) also reported that corms, cormels and leaves were the parts of taro used. According to Rao et al. (2010), lipids, proteins, amino acids and sugars present in corms all give rise to volatile compounds when taro is cooked which contribute to the flavor.

\section{Previous information on the availability, cultivation and utilization of taro}

Taro was mainly available in the surveyed regions through cultivation. However, taro can be obtained from naturally occurring areas like marshy zones. The name of the cultivar grown by farmers in the Ashanti region is "Kooko broni", while the cultivars grown in the other regions were not known. The study identified that taro is not a difficult-to-grow crop as even soils with marginal fertility and flooding could support its growth in addition to conditions such as well-drained soil and high rainfall. It was also identified that taro is mainly cultivated during the rainy season probably due to its high moisture requirement. Antwi et al. (2017) reported that taro is usually planted in Ghana at the onset of the major rainy season and the field is maintained by weeding it. The selling of taro provided extra income, while the rest used to cultivate for subsistence use only. Antwi et al. (2017) reported that majority of taro farmers cultivated taro for their personal use only.

\section{Current information on cultivation and utilization of taro}

Although majority of the respondents reported taro to still be under cultivation in the Bono, Western and Eastern regions, quite a higher number reported that the crop is no longer cultivated, especially in the Ashanti region. Also, quite a higher figure from the four regions has stopped using taro as food and also for trading.

\section{Possible causes of taro endangerment}

Major causes of taro endangerment identified were lack of healthy planting materials associated with cultivation which might have resulted in the unavailability of consumable corms. This has led to most consumers not consuming taro because it is no longer available to them. Some consumers have stopped consuming taro due to the associated ill-health. Reported ill-health/diseases were "Piles" resulting from the acridity and reduced sexual function. According to Tetteh (2017), eating taro can lead to kidney stones and gout as well as other health complications if it is not prepared properly by boiling for the recommended amount of time. It can also be steeped in water overnight before cooking to further reduce the amount of oxalates. To absolutely minimize risk, milk or other calcium-rich foods should be eaten with taro in order to block oxalate absorption. Taro traders in the Ashanti, Western and regions have also stopped trading taro due to unavailability. Antwi et al. (2017) reported that the outbreak of the TLB disease and inadequate healthy planting materials were the major constraints to large-scale production of taro in Ghana. TLB disease has been perceived to be responsible for the loss of taro germplasm, which grew naturally in flooded areas without being cultivated (Antwi et al. 2017). Yield losses to TLB by up to 50 per cent for corms and 95 per cent for leaves have been reported (Nelson et al. 2011; Singh et al. 2006). Phytophthora colocasiae has been identified as the main causative agent of the disease (Omane et al. 2012). According to Singh et al. (2012), TLB poses a grave threat to food security and loss of crop genetic diversity, as well as impact on personal incomes and national economies if not controlled. Antwi et al. (2017) also reported the outbreak of the disease to the use of agrochemicals in farming practices in recent times.

\section{Possible remedies for taro endangerment}

According to respondents, the first major factor that could sustain taro in the surveyed regions is the use of disease-resistant varieties. This may probably reduce the problem associated with the loss of healthy planting materials as one of the major causes of taro extinction. The second remedy to taro extinction, according to the respondents, is to explore and publicize the nutritional benefits of taro so as to encourage consumption and/or utilization. This could put a high demand on the crop and encourage its cultivation. A few respondents (15), however, reported that publicizing the fact that taro has a short maturity period than most other root tuber crops could contribute to sustainability.

\section{Conclusions}

The study revealed that aged males who are mostly illiterates show much interest in the cultivation of taro. The study also showed different vernacular names of the cultivated forms of taro are due to differences in ethnicity. 
Corms are the main parts of taro used as food and are usually prepared into "Puree or Ampesi" before eaten. The availability of taro in the study areas is mainly through cultivation. Taro could be cultivated in various soils, even those with marginal fertility as well as under flooded conditions, especially during the rainy seasons and on a subsistence scale. Also, quite a greater number of farmers still cultivate taro in the Bono, Western and Eastern regions. Major causes of taro endangerment identified included lack of healthy planting materials, unavailability of consumable corms and ill-health. Suggestions made for the sustainability of taro in Ghana included the use of disease-resistant cultivars and exploring and publicizing the nutritional benefits of the crop.

\section{Abbreviations}

FAO: Food and Agriculture Organization; FAOSTAT: Food and Agriculture Organization Statistics; GSS: Ghana Statistical Service; JHS: Junior High School; MoFA: Ministry of Food and Agriculture; SHS: Senior High School; SPSS: Statistical Package for Social Sciences; STMA: Sekondi-Takoradi Metropolitan Assembly; TLB: Taro Leaf Blight; TLBD: Taro Leaf Blight Disease; WAAP: West Africa Agricultural Productivity Programme.

\section{Acknowledgements}

Not applicable.

\section{Authors' contributions}

EO conceived the original idea, administered the questionnaires for data collection and wrote the first draft of the manuscript. EFD read the first draft of the manuscript for necessary corrections. EA designed the questionnaires and performed analytical computations. All authors read and approved the manuscript for submission.

\section{Funding}

No funding was obtained for this study.

\section{Availability of data and materials}

The data used to support the findings of this study are available from the corresponding author upon request.

\section{Declarations}

Ethics approval and consent to participate Not applicable.

\section{Consent for publication}

Not applicable.

\section{Competing interests}

The authors declare that they have no conflict of interest.

\section{Author details}

'Plantation Department, Norpalm Ghana Limited, Takoradi, Western Region, Ghana. ${ }^{2}$ Department of Horticulture and Crop Production, University of Energy and Natural Resource, Sunyani, Ghana. ${ }^{3}$ Department of Crop and Soil Science, College of Agriculture Education, University of Education, Winneba, Ashanti-Mampong, Ghana.
Received: 14 April 2021 Accepted: 9 July 2021

Published online: 19 July 2021

\section{References}

Akpavi S, Wala K, Gbogbo KA, Odah K, Woegan YA, Batawila K, Akpagana K (2012) Distribution spatiale des plantes alimentaires mineures ou menacées de disparition au Togo: un indicateur de l'ampleur de leur menace. Acta Bot Gallica 159(4):411-432

Antwi NA, Aboagye LM, Osei-Kofi PS, Asiedu-Darko E (2017) Germplasm collection and ethnobotany of taro (Colocasia esculenta L. Schott) from nineteen districts in the Ashanti, Eastern and Western regions of Ghana. Ghana J Agric Sci 51:53-61

Barbieri R, Costa Gomes J, Alercia A, Padulosi S (2014) Agricultural biodiversity in Southern Brazil: integrating efforts for conservation and use of neglected and underutilized species. Sustainability 6(2):741-757

Bradbury JH, Nixon RW (1998) The acridity of raphides from the edible aroids. J Sci Food Agric 76(4):608-616

Darkwa S, Darkwa AA (2013) Taro (Colocasia esculenta): it's utilization in food products in Ghana. J Food Process Technol 4(5):1-7

Ecoport (2010). Ecoport database. Ecoport. https://www.feedipedia.org/node/ 537

Food and Agricultural Organization of United Nations (FAO) (2008). Publication report. http://www.fao.org

Food and Agriculture Organisation Statistical (FAOSTAT) (2017) The data set "Taro, production quantity (tons)" for Ghana, contains data from the year 1961 until 2017.

Ghana Statistical Service (2010). Kumasi metropolitan. 92. www.statsghana.gov.gh.

Ghana Statistical Service (2014) Ahanta West. District Analytical Report-Ahanta West 2010 Population and Housing Census. Ghana Statistical Service. Retrieved from http://mofa.gov.gh/site/?page_id=1767

McGregor A, Afeaki P, Armstrong J, Hamilton A, Hollyer J, Masamdu R, Nalder K (2011) Pacific Island taro market access scoping study. Facilitating Agricultural Commodity Trade (FACT) Project, the Secretariat of the Pacific Community (SPC)

MoFA, G. (2010). East Akim Municipal. 2010, 1. http://mofa.gov.gh/site/?page_ $\mathrm{id}=1510$

Mwenye OJ (2009) Genetic diversity analysis and nutritional assessment of cocoyam genotypes in Malawi (Doctoral dissertation, University of the Free State)

Nelson S, Brooks F, Teves G (2011) Taro leaf blight in Hawaii. Plant Disease Bulletin No. PD-71

Nyarko P (2010) Dormaa municipality, pp 1-94

Ofori K (2004) Comparison of taro production and constraints between West Africa and the Pacific. School of Agriculture, University of the South Pacific, Alafua Campus

Omane E, Oduro KA, Cornelius EW, Opoku IY, Akrofi AY, Sharma K, Bandyopadhyay R (2012) First report of leaf blight of taro (Colocasia esculenta) caused by Phytophthora colocasiae in Ghana. Plant Dis 96(2):292-292

Onwueme IC (1999) Taro cultivation in Asia and the Pacific. Rap Publ 16:1-9

Onyeka J (2014) Status of cocoyam (Colocasia esculenta and Xanthosoma spp) in West and Central Africa: production, household importance and the threat from leaf Blight. CGIAR Research Program on Roots, Tubers and Bananas (RTB)

Quero-Garcia J, Ivancic A, Lebot V (2010) Taro and cocoyam. In: Root and tuber crops. Springer, New York, NY, pp 149-172

Rao VR, Matthews PJ, Eyzaguirre PB, Hunter D (2010) The global diversity of Taro: ethnobotany and conservation

Safo-Kantaka O (2004). Colocasia esculenta (L.) Schott. Record from Protabase. PROTA (Plant Resources of Tropical Africa/Ressources végétales de l'Afrique tropicale)[ed. by Grubben, GJH\Denton, O. A.]. Wageningen, Netherlands: PROTA 
Singh D, Guaf J, Okpul T, Wiles G, Hunter D (2006) Taro (Colocasia esculenta) variety release recommendations for Papua New Guinea based on multilocation trials. N Z J Crop Hortic Sci 34(2):163-171

Singh D, Jackson G, Hunter D, Fullerton R, Lebot V, Taylor M, Tyson J (2012) Taro leaf blight—a threat to food security. Agriculture 2(3):182-203

Subedi R, Karki M, Panday D (2020) Food system and water-energy-biodiversity nexus in Nepal: a review. Agronomy 10(8):1129

Taylor M, Hunter D, Rao VR, Jackson GVH, Sivan P, Guarino L (2010) Taro collecting and conservation in the Pacific Region. The Global Diversity of Taro: Ethnobotany and Conservation, 150-167
Tetteh E (2017) The Nutrition of Taro. https://www.gbcghana.com/1.5232638 United Nations Food and Agriculture Organisation Statistical (FAOSTAT) Database Agricultural production of primary crops (2015) FAO, Rome

\section{Publisher's Note}

Springer Nature remains neutral with regard to jurisdictional claims in published maps and institutional affiliations.

\section{Submit your manuscript to a SpringerOpen ${ }^{\circ}$ journal and benefit from:}

- Convenient online submission

- Rigorous peer review

- Open access: articles freely available online

- High visibility within the field

- Retaining the copyright to your article

Submit your next manuscript at $\boldsymbol{\sim}$ springeropen.com 